\title{
SYNTHESIZING TEST REFERENCE YEAR FILES FROM KNOWN CLIMATE PATTERNS OF NEARBY CITIES
}

\section{CONSTRUÇÃO DE ARQUIVOS TRY A PARTIR DE PADRÕES CLIMÁTICOS CONHECIDOS DE CIDADES PRÓXIMAS}

\author{
José Aderson Araújo Passos Filho ${ }^{1}$ \\ Universidade Federal do Ceará, Fortaleza, CE, Brazil, aderson.passos@gmail.com \\ Bruno de Paiva y Raviolo ${ }^{2}$ \\ Universidade Federal do Ceará, Fortaleza, CE, Brazil, bruno.raviolo@gmail.com \\ Natasha Catunda ${ }^{3}$ \\ Eidgenössische Technische Hochschule, Zurich, ZH, Switzerland, n.catunda@gmail.com \\ Nayana Helena Barbosa de Castro ${ }^{4}$ \\ Universidade Federal do Rio Grande do Norte, Fortaleza, CE, Brazil, nayanahelena@gmail.com \\ Karoline Cordeiro de Andrade ${ }^{5}$ \\ Universidade Federal do Ceará, Fortaleza, CE, Brazil, karolinecordeiro.arquiteta@gmail \\ Daniel Ribeiro Cardoso ${ }^{6}$ \\ Universidade Federal do Ceará, Fortaleza, CE, Brazil, danielcardoso@ufc.br
}

\begin{abstract}
The importance of an architecture adapted to its climatic context is often debated. In order to avoid future unexpected environmental behavior or failure of a building during its use, building simulation tools are used in the design and require complete and consistent weather data. However, such data are not always available for the locations where buildings are simulated, and the use of data from neighboring cities becomes usual. There are, though, several uncertainties involved in the behavior of environmental variables when the climate of large urban centers is attributed to nearby localities and areas with more significant vegetation cover, water bodies, different topography, among others. The present paper aims to present the process of preparing a weather file for the Pecém Industrial and Port Complex, located at $40 \mathrm{~km}$ from the capital Fortaleza, Brazil, in order to be used in simulations during the design process of buildings. The synthesis of the file was achieved through the collection and treatment of information measured in loco, the application of recommended models for the estimation of missing data, and the development of an alternative method for the estimation of a Test Reference Year of localities without weather data of several years.
\end{abstract}

Keywords: Weather file. Thermal energy simulation. Thermal comfort. Passive architecture. Low energy architecture.

\section{Resumo}

A importância de uma arquitetura adaptada ao seu contexto climático é frequentemente discutida. Para evitar um comportamento ambiental futuro inesperado ou falha durante o uso de um edifício, ferramentas de simulação são usadas em projeto e exigem dados meteorológicos completos e consistentes. No entanto, esses dados nem sempre estão disponíveis para os locais onde os edifícios são simulados e o uso de dados das cidades vizinhas se torna algo comum. Existem, no entanto, algumas incertezas envolvidas no comportamento de variáveis ambientais quando o clima dos grandes centros urbanos é atribuído a localidades próximas e áreas com maior cobertura vegetal, corpos hídricos, topografia diferente, entre outros. O presente trabalho tem como objetivo apresentar o processo de elaboração de um arquivo climático para o Complexo Industrial e Portuário do Pecém, a $40 \mathrm{~km}$ da capital Fortaleza, a fim de ser utilizado em simulações durante o processo de projeto de edificações. A síntese do arquivo foi realizada por meio da coleta e tratamento de informações medidas in loco, da aplicação de modelos recomendados para a estimativa de dados inexistentes e do desenvolvimento de um método alternativo para a estimativa de um Test Reference Year de localidades sem dados meteorológicos de vários anos.

Palavras-chave: Arquivo climático. Simulação termoenergética. Conforto térmico. Arquitetura passiva. Eficiência energética.

How to cite this article:

PASSOS FILHO, J.A.A. et al.. Synthesizing Test Reference Year files from known climate patterns of nearby cities. PARC

Pesquisa em Arquitetura e Construção, Campinas, SP, v. 10, p. e0190X, 2019. ISSN 1980-6809.

DOI:http://dx.doi.org/10.20396/parc.v10i0.8653706 


\section{Introduction}

The importance of an architecture adapted to its climatic context is often debated. Due to this necessity, computational tools can help and assist designers and clients in making assertive decisions. These simulation software tools estimate energy consumption in buildings before their construction or retrofit, according to their characteristics, and can achieve more efficient architectural and technological solutions (FERREIRA; BUORO, 2015). Around the world, the increasing requirement for quantification of energy consumption in buildings makes computational simulations of energy and environmental performance an essential part of the design process (GONÇALVES.; BRUNELLI; BODE, 2015). In order to avoid unexpected behavior or failure during its use, building simulation tools require complete and consistent weather data, which implies the application of pre-processing, correction and interpolation techniques for the correction of erroneous or missing data (BARNABY; CRAWLEY, 2011).

This work addresses the need for a weather file in a research project that involves the construction of an experimental building located in the Industrial and Port Complex of Pecém (CIPP), at the coast of the state of Ceará, in Brazil. The building will serve as a case study to analyze the crucial role of simulations to evaluate the performance of the building's subsystems in order to reduce its energy consumption. It is a partially airconditioned building, which follows the paradigm of bioclimatic architecture and is oriented to reduce the consumption of its active systems during its operation. With this in mind, the design process of the building requires an investigation of the environmental parameters in order to enable a seamless environmental integration (BARNABY; CRAWLEY, 2011), which involves the elaboration and analysis of a climatic file compatible with the simulation engine to be used.

The present article aims to present the process of preparing a weather file for the Pecém Industrial and Port Complex, in order to be used in computer simulations during the design process of buildings. The weather file was obtained from the collection and treatment of information measured in loco, the application of recommended models to estimate missing data, and the development of an alternative method to estimate a Test Reference Year' (TRY) of localities without measured climatic data for several years.

\section{Method}

\section{Environmental context}

The CIPP is a non-consolidated industrial zone, with the ostensible presence of native vegetation and few industrial facilities installed up to now (ASSEMBLÉIA LEGISLATIVA DO ESTADO DO CEARÁ, 2013). According to the NBR classification, the site is within the bioclimatic zone 8 , characterized by a hot and humid climate that covers $53.7 \%$ of the national territory (ABNT, 2005).

The use of thermal energy, daylighting, and natural ventilation simulations foreseen in the experimental building design process requires a concise and coherent climatic file for the correct use of the simulation models. Such a need, in turn, requires the meticulous analysis of a multi-year database, based on data collected on or near the site itself, in order to reduce distortions in the results (BARNABY; CRAWLEY, 2011).

However, there is no weather file available for this region in the National Institute of Meteorology (INMET) or Solar and Wind Energy Resource Assessment (SWERA) program databases ${ }^{2}$. The nearest available weather file is for the capital, Fortaleza. Although proximity is essential and the geographical context is the same, there are several uncertainties involved in the behavior of environmental variables when 
comparing Fortaleza's weather, the country's fifth-largest city, with an area with dense vegetation cover still to be occupied by industries.

Also, hourly recorded climatic data in order to create weather files to simulate the thermal performance of buildings are usually scarce and of poor quality. There are few automatic stations in Brazil that provide hourly data of dry bulb temperature, wet bulb temperature or relative humidity, wind direction, wind speed, cloud cover, and atmospheric pressure. There are even fewer stations that measure solar radiation, a necessary variable to complete the series of minimum data used to compile a weather file (LabEEE, 2005).

The weather file preparation for the Pecém district was carried out based on data provided either by meteorological agencies or collected by local stations of logistics and transportation companies located in the port complex. Theoretical models were used to estimate the missing information, according to recommendations made by LabEEE (2005), since the collected data was related to only one year of measurements and part of the data required to assemble an *.EPW ${ }^{3}$ format weather file was absent. The tested methods to calculate solar radiation were the Kasten model, described by Thevenard and Brunger (2001), with the coefficients adapted by LabEEE (2005) for Brazilian cities, and the Pitta (2001) method.

The coefficients provided by LabEEE (2005) used to calculate the two models did not have specific values for the Pecém district. Therefore, they were evaluated according to the proximity of their respective cities to the place of interest, and the validity and similarity of the results were calculated with known values of the neighboring capital.

In addition to these recommended models, a new method here presented was also used to estimate the Test Reference Year (TRY). The new method is applied when: the only climatic data available refers to a specific year of the analyzed site; data from a nearby city with a TRY file is available for the same year, and the TRY file itself of the nearby city is also available.

Two weather files were then created for Pecém, one for the year 2012 and the other an estimated Test Reference Year. Those files, together with Fortaleza's Test Reference Year archive (SWERA), were tested in Euclid, a plug-in for SketchUp modeling tool developed by Big Ladder Software, which is an open-source software that works with the EnergyPlus engine. The test was performed to understand the relevance of the difference between the climates of Pecém and Fortaleza, therefore indicating the need to develop a specific weather file for the former..

\section{Data collection}

Data were collected from instruments installed at the height of 15 meters above sea level at Pier 2 of Pecém Port, as shown in Figure 1 , at coordinates of approximately $-3.54^{\circ}$ latitude and $-38.80^{\circ}$ longitude, $40 \mathrm{~km}$ distant from Fortaleza. The set of instruments were contained in a WXT510 Weather Transmitter device, manufactured by Vaisala and warranted by Campbell Scientific, Inc. The device measures wind speed and direction, precipitation, barometric pressure, temperature, and relative humidity. Wind direction is not measured when the wind speed drops below $0.05 \mathrm{~m} / \mathrm{s}$. In this case, the last calculated direction output remains until wind speed increases. The device's main internal module is housed in a naturally aspirated radiation shield that protects it and reflects solar radiation (CAMPBELL SCIENTIFIC, 2007). 
PASSOS, J.A.A.; RAVIOLO, B. P. Y; MOTA, N. M. C. T.; CASTRO, N. H. B.; ANDRADE, K. C.; CARDOSO, D. R.

Synthesizing Test Reference Year files from known climate patterns of nearby cities

Figure 1 - Location of measuring instruments

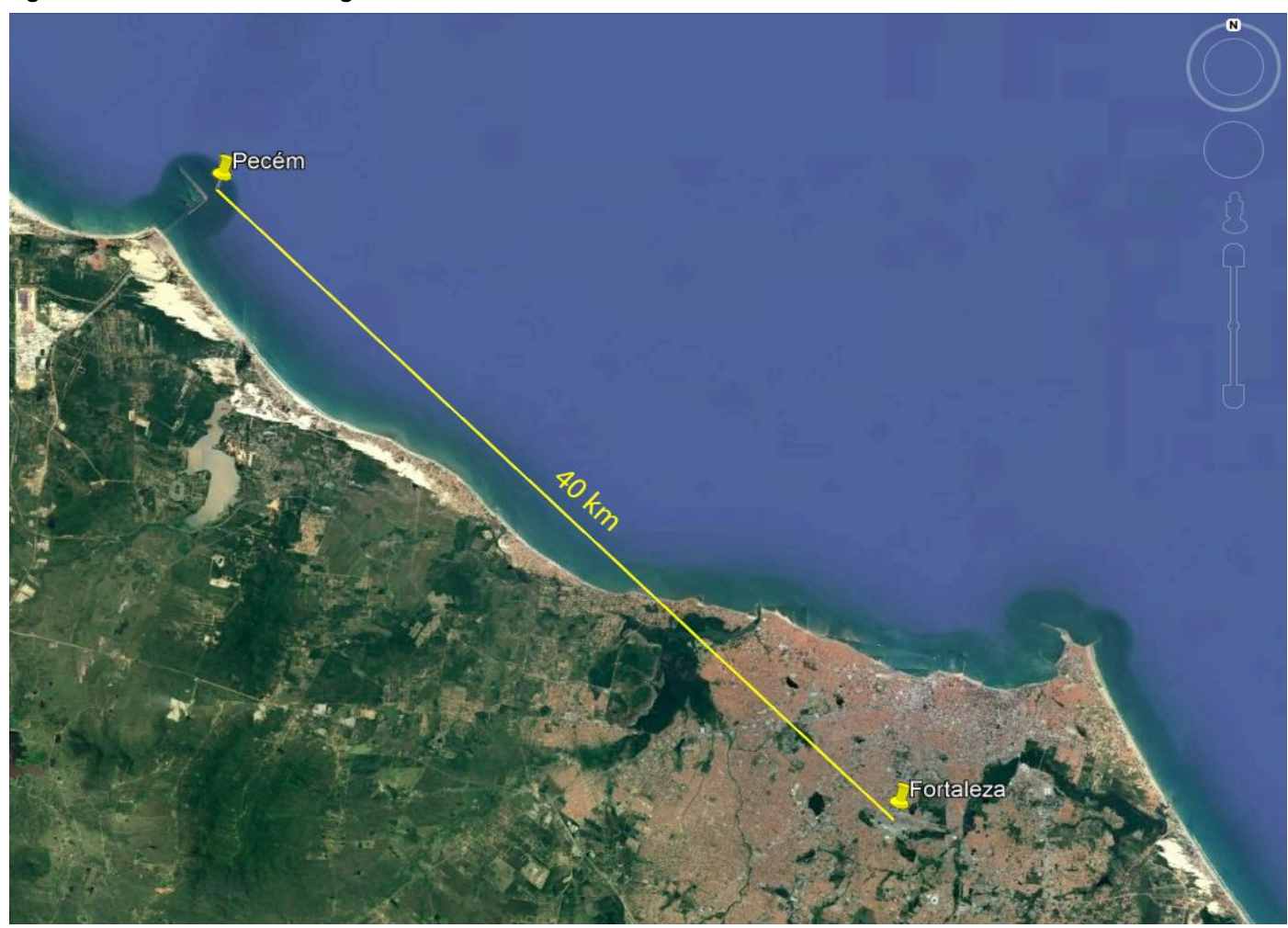

Source: Google Maps.

A climatic report referring to 2012 was used to prepare the weather file of Pecém, containing information of dry bulb temperature, relative humidity, atmospheric pressure, wind speed, and wind direction - all measured in 3-minute intervals. Hourly averages were calculated, and a preliminary weather file was compiled in the *.EPW format, still lacking four pieces of information, to be later estimated: cloud cover and global horizontal, direct normal and diffuse horizontal radiations.

Given the proximity of Fortaleza to Pecém and the availability of a Test Reference Year for Fortaleza, Pecém's cloud cover values were estimated from Fortaleza's 2012 monthly averages, obtained from the World Weather Online website ${ }^{4}$. According to representatives of the website, the World Weather Online runs a weather model based in validated models and instruments such as NASA Weather Satellite Imagery, NOAA GFS2 model and JMA model - all of those used by meteorological centers such as the European Centre for Medium-Range Weather Forecasts and the World Meteorological Organization (SUPPORT, 2019). Those averages were then adjusted according to the hourly values, with the help of the Elements open-source tool, from Big Ladder Software. Thus, the cloud cover hourly values of the Fortaleza TRY file were normalized by Elements monthly, and monthly averages were generated, as the real averages obtained for 2012 to Pecém. Figure 2 shows how the shape of the annual cloud cover curves of the two localities resemble each other, but generating different monthly averages, with an offset that corresponds to a difference of $41.2 \%$ from the values of Fortaleza to the values of Pecém. 
Figure 2 - Annual cloud cover curve adjusted for Pecém (blue), from Fortaleza's annual cloud cover curve (red)

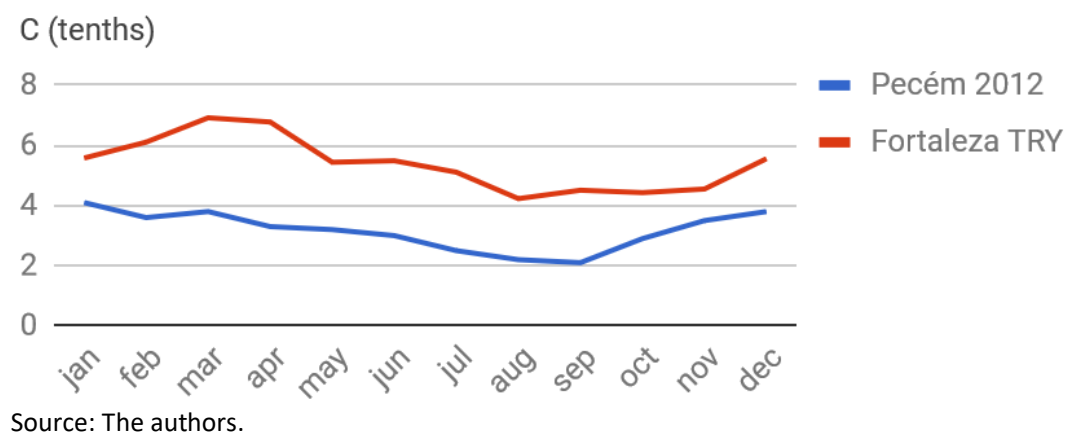

\section{Data synthesizing}

The scarcity of stations that measure solar radiation, which is essential information to evaluate the thermal performance of buildings in a tropical country with a high incidence of solar radiation (LabEEE, 2005), makes it challenging to develop weather files. Therefore, this climatic variable becomes especially important in regions of lower latitudes, such as the district of Pecém. However, the few weather stations distributed irregularly in the Brazilian territory - which is a country of significant variation of latitudes, sky conditions and atmospheric turbidity - require the construction of weather files not to be limited to just compiling data to the format of the program to be used, but to also include the treatment of the data with the proper adjustments of failures and the development of models and coefficients that represent the phenomena of unmeasured data (LABEEE, 2005).

Two methods to obtain estimated values for global horizontal solar radiation were tested. According to LabEEE (2005), these methods were initially developed for a specific selection of Brazilian cities and from studies initially based on European cities of higher latitudes. In none of these cases, the locality of interest of the present study was contemplated. Thus, coefficients from localities near Pecém were chosen to compare possible levels of radiation for Pecém and known values from Fortaleza.

The first method used to obtain the estimated values of global horizontal radiation is the Kasten model (THEVENARD; BRUNGER, 2001), which is considered relatively simple and easy to use (LABEEE, 2005). It uses another model, Metstat (THEVENARD; BRUNGER, 2001), for clear sky calculations (Equation 1), which is embedded in the Kasten equation for cloud-covered skies (Equation 2). It considers Linke's turbidity factor, taken from the Solar Radiation Data (SoDa) website maps5 (Figure 3); air mass; cloud cover (measured in tenths, regardless of the type of cloud formation) and specific coefficients of the locality of interest. Here, as stated by LabEEE (2005), any sky with cloud cover levels higher than o tenths, in an integer domain ranging from 0 to 10 (from $0 \%$ to $100 \%$, in increments of $10 \%$ ), should be considered a cloud-covered sky. In both localities of interest, no clear sky condition was identified in any of the data acquired for this study.

The global horizontal radiation for clear sky $I_{g}^{\prime}$ and for cloud covered sky $I_{g}$ are then given by the equations:

$I^{\prime} g=G_{o} \cdot A \cdot \exp \left(-B \cdot T_{l} \cdot m\right)$

$I_{g}=I_{g}^{\prime} \cdot\left(1-a \cdot C \cdot A^{b}\right)$

Where:

- $I_{g}^{\prime}$ is the global horizontal radiation for clear skies in $\mathrm{W} / \mathrm{m}^{2}$; 
- $I_{g}$ is the global horizontal radiation for cloud covered skies in $\mathrm{W} / \mathrm{m}^{2}$;

- $G_{o}$ is the extraterrestrial radiation in $\mathrm{W} / \mathrm{m}^{2}$;

- $T_{l}$ is Linke's turbidity factor;

- $m$ is the air mass;

- $\quad C$ is the cloud cover in tenths;

- $\quad a, b, A$ e $B$ are specific coefficients for each locality.

The calculation of the extraterrestrial radiation $G_{o}$ is given as in Equation 3:

$G_{o}=G_{s c} \cdot\left(1+0.033 \cdot \cos \left(\frac{360 \cdot n}{365}\right)\right) \cdot(\cos (\varphi) \cdot \cos (\delta) \cdot \cos (\omega)+\sin (\varphi) \cdot \sin (\delta))$

Where:

- $G_{O}$ is the extraterrestrial radiation in $\mathrm{W} / \mathrm{m}^{2}$;

- $G_{S C}$ is the solar constant, approximately $1367 \mathrm{~W} / \mathrm{m}^{2}$;

- $n$ is the day of the year, where: $\left\{n \in \mathbb{N}^{*} \mid n \leq 365\right\}$;

- $\varphi$ is the latitude of the locality in degrees;

- $\delta$ is the declination of the terrestrial globe in degrees;

- $\omega$ is the hour angle in degrees, where: $\{\omega \in \mathbb{R} \mid-180 \leq \omega \leq 180\}$.

Wherein the declination of the terrestrial globe $\delta$ can be approximated as described in Equation 4:

$\delta \approx 23.45 \cdot \sin \left(360 \cdot \frac{284+n}{365}\right)$

Where:

- $\delta$ is the declination of the terrestrial globe in degrees;

- $n$ is the day of the year, where: $\left\{n \in \mathbb{N}^{*} \mid n \leq 365\right\}$.

The Linke $T_{l}$ turbidity factor, according to the SoDa project ${ }^{5}$, is an approximation used to represent the absorption and diffusion properties of solar radiation under clear sky conditions. It describes the optical thickness of the atmosphere as a function of the absorption by water vapor and the absorption and diffusion by aerosol particles concerning a dry and clean atmosphere. The higher the Linke's turbidity factor, the greater the attenuation of the solar radiation through a clear sky atmosphere. Figure 2 shows a map of for January 2003, with air mass equal to 2 . 
PASSOS, J.A.A.; RAVIOLO, B. P. Y; MOTA, N. M. C. T.; CASTRO, N. H. B.; ANDRADE, K. C.; CARDOSO, D. R.

Synthesizing Test Reference Year files from known climate patterns of nearby cities

Figure 3 - Linke's turbidity factor for the month of January of 2003

$T L(A M 2)(j \circ n)$

1.0

3.0

4.5

6.5

Copyright Meteotest - Armines - Ecole des Mines de Paris, 2002

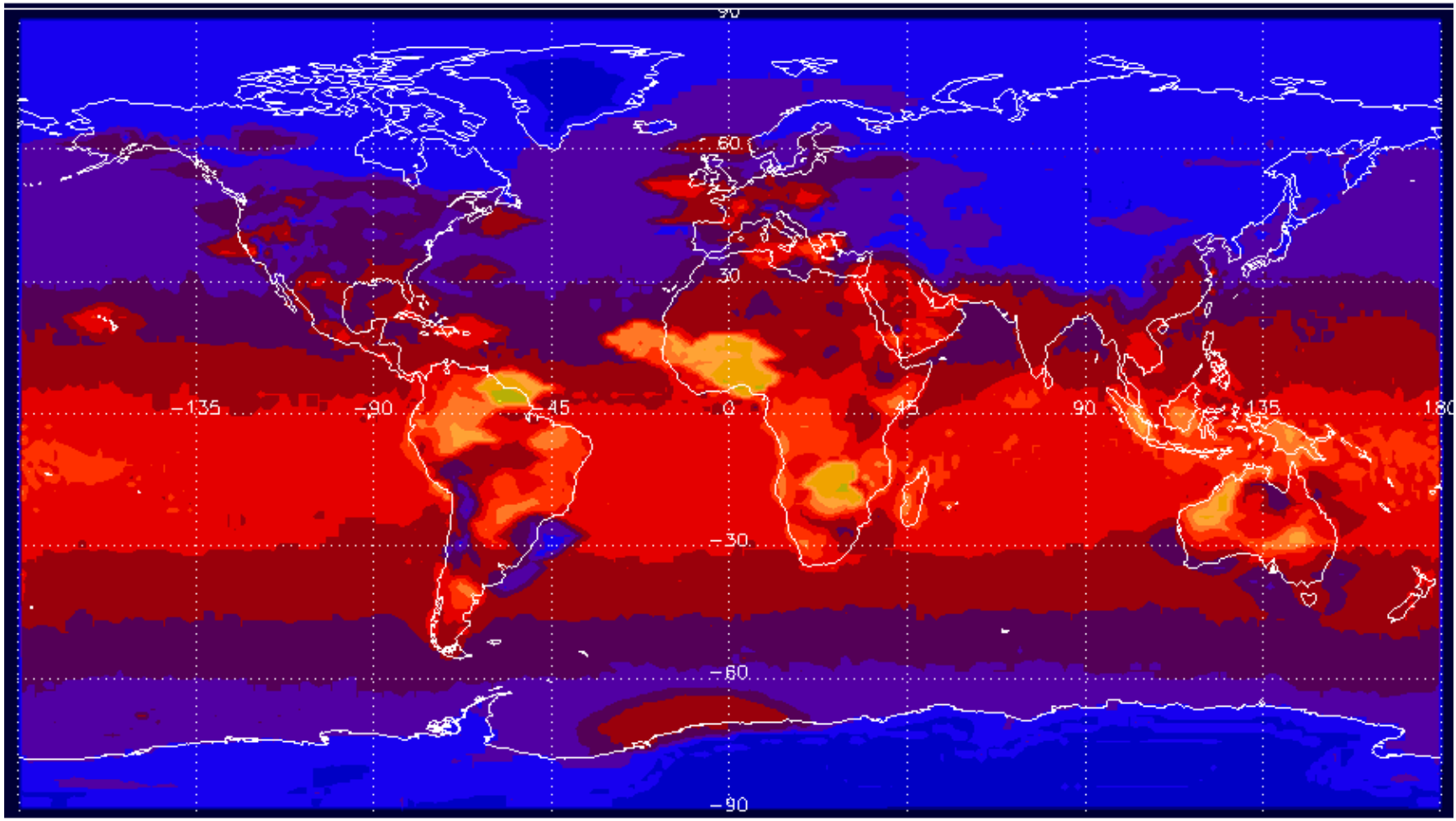

Source: SoDa .

The Linke turbidity factors for the district of Pecém were taken from the maps for each month from January to December 2003, the only year compiled by this source until the present moment. The result is shown in Table 1.

Table 1 - Linke's turbidity factor

\begin{tabular}{ccccccccccccc}
\hline \multicolumn{11}{c}{ Linke's turbidity factor $\boldsymbol{T}_{\boldsymbol{l}}$ for Pecém } \\
\hline January & Feb. & March & April & March & June & July & August & Sept. & Oct. & Nov. & Dec. \\
\hline 4.2 & 4.2 & 4.7 & 4.2 & 3.7 & 4.2 & 3.7 & 3.7 & 3.7 & 4.2 & 4.2 & 4.2 \\
\hline
\end{tabular}

Source: SoDa ${ }^{5}$.

The air mass $m$ is the relation that explains the attenuation of the solar radiation due to the atmosphere at a particular moment of the year in comparison to the minimum attenuation, that is when the zenith angle is $0^{\circ}$. This value is, in a simplified way, calculated as the inverse of the cosine of the zenith angle. However, due to the heterogeneity of the atmospheric density and refractive effects of radiation along its path through the atmosphere, NREL (1995) corrects the calculation of the air mass $m$ according to Equation 5:

$m=\frac{P}{P_{\text {ref }}} \cdot \frac{1}{\cos (\theta)+0.50572 \cdot(96.07995-\theta)^{-1.6364}}$

Where:

- $m$ is the air mass;

- $\quad P$ is the local atmospheric pressure in $\mathrm{Pa}$; 
- $\quad P_{r e f}$ is the reference atmospheric pressure, equal to $101325 \mathrm{~Pa}$;

- $\theta$ is the zenith angle in degrees.

The cosine of the zenith angle is defined according to the calculation presented by Duffie and Beckman (1991), in Equation 6:

$\cos (\theta)=\cos (\varphi) \cdot \cos (\delta) \cdot \cos (\omega)+\sin (\varphi) \cdot \sin (\delta)$

Where:

- $\theta$ is the zenith angle in degrees;

- $\varphi$ is the local latitude in degrees;

- $\delta$ is the declination of the terrestrial globe in degrees;

- $\omega$ is the hour angle in degrees, where: $\{\omega \in \mathbb{R} \mid-180 \leq \omega \leq 180\}$.

Table 2 shows the coefficients $a, b, A$ and $B$ from the Kasten model for four Brazilian cities: Belém, Brasília, Recife and São Paulo. We can observe that Recife's coefficients $A$ and $B$ differ considerably from those of Belém. Brasília, which is located at a higher latitude compared to Recife and Belém, presents intermediate values, suggesting that these coefficients are not well explained exclusively by the different latitudes of the locations. Also, the sampling is not sufficiently large to allow performing a regression analysis, in order to estimate the coefficients of the Pecém district. Moreover, it was observed that the global horizontal radiation values calculated with the coefficients of Belém are closer to the values of Fortaleza than the radiation calculated with the Recife coefficients. Therefore, the definition of the coefficients $a, b, A$ and $B$ from the Kasten model was based on the values adjusted by LabEEE (2005) for the city of Belém.

Table 2- Estimated coefficients for the Kasten method
\begin{tabular}{cccccc}
\hline City & Latitude & $\boldsymbol{a}$ & $\boldsymbol{b}$ & $\boldsymbol{A}$ & $\boldsymbol{B}$ \\
\hline Belém & $1^{\circ} 27^{\prime} 18^{\prime \prime}(\mathrm{S})$ & 0.016 & 0.009 & 0.30 & 0.010 \\
\hline Brasília & $15^{\circ} 46^{\prime} 48^{\prime \prime}(\mathrm{S})$ & 0.020 & 0.012 & 3.15 & 0.020 \\
\hline Recife & $8^{\circ} 03^{\prime} 14^{\prime \prime}(\mathrm{S})$ & 0.010 & 0.009 & 3.60 & 0.028 \\
\hline São Paulo & $23^{\circ} 32^{\prime} 56^{\prime \prime}(\mathrm{S})$ & 0.034 & 0.082 & 7.00 & 0.034 \\
\hline
\end{tabular}

Source: adapted from LabEEE (2005).

\section{Adjusted Pitta method (LabEEE method)}

The second method used to obtain global horizontal radiation estimated values, the Pitta model, uses the hourly cloud cover $C$, the global horizontal extraterrestrial radiation $G_{o}$, coefficients $a$ and $b$, estimated monthly, and $c$, estimated monthly for several cities, among them Fortaleza (Table 3 ). The calculation is given according to Equation 7:

$I_{g}=G_{O} \cdot\left(c+b \cdot\left(\frac{C}{10}\right)+a \cdot\left(\frac{C}{10}\right)^{2}\right)$

Where:

- $I_{g}$ is the global horizontal radiation in $\mathrm{W} / \mathrm{m}^{2}$;

- $G_{O}$ is the extraterrestrial radiation in $\mathrm{W} / \mathrm{m}^{2}$;

- $\quad a, b$ and $c$ are monthly coefficients. 
PASSOS, J.A.A.; RAVIOLO, B. P. Y; MOTA, N. M. C. T.; CASTRO, N. H. B.; ANDRADE, K. C.; CARDOSO, D. R.

Synthesizing Test Reference Year files from known climate patterns of nearby cities

\begin{tabular}{|c|c|c|c|c|c|c|c|c|c|c|c|c|}
\hline & Jan. & Feb. & Mar. & Apr. & Mar. & Jun. & Jul. & Aug. & Sep. & Oct. & Nov. & Dec. \\
\hline$a$ & -0.50 & -0.50 & -0.50 & -0.39 & -0.26 & -0.46 & -0.64 & -0.66 & -0.58 & -0.77 & -0.60 & -0.40 \\
\hline$b$ & +0.10 & +0.10 & +0.10 & -0.04 & -0.08 & +0.03 & +0.14 & +0.23 & +0.15 & +0.29 & +0.20 & -0.10 \\
\hline$c_{F}$ & +0.74 & +0.77 & +0.81 & +0.82 & +0.75 & +0.73 & +0.71 & +0.67 & +0.69 & +0.62 & +0.73 & +0.79 \\
\hline
\end{tabular}

Source: adapted from LabEEE (2005).

\section{Direct normal radiation calculations}

The global horizontal radiation hourly values, besides being part of a *.EPW file is not currently used in the EnergyPlus software calculations but is necessary to obtain the direct normal and diffuse horizontal components.

From global horizontal radiation, direct horizontal and diffuse horizontal radiations were calculated using formulas described by Liu and Jordan (1960), in Equations 8 to 12, to estimate the coefficients of direct and diffuse transmission. Direct normal radiation is obtained by the values of direct horizontal radiation, using correction formulas for the maximum values of direct horizontal radiation, calculated as a function of other variables, according to Equations 13 and 14 .

$\frac{I_{g}}{G_{o}}=\tau_{b}+\tau_{d}$

$\tau_{d}=0.271-0.294 . \tau_{b}$

Therefore:

$\tau_{b}=\frac{I_{g}}{G_{o}}-\tau_{d} \Rightarrow \tau_{d}=0.384-0.289 .\left(\frac{I_{g}}{G o}\right)$

And:

$I_{b}=\tau_{b} \cdot G_{o}$

$I_{d}=\tau_{d} \cdot G_{o}$

Where:

- $I_{g}$ is the global horizontal radiation in $\mathrm{W} / \mathrm{m}^{2}$;

- $G_{o}$ is the extraterrestrial radiation in $\mathrm{W} / \mathrm{m}^{2}$;

- $\tau_{b}$ is the direct transmission coefficient;

- $\tau_{d}$ is the diffuse transmission coefficient;

- $I_{b}$ is the horizontal direct radiation in $\mathrm{W} / \mathrm{m}^{2}$;

- $I_{d}$ is the horizontal diffuse radiation in $\mathrm{W} / \mathrm{m}^{2}$.

Furthermore, according to Duffie and Beckman (1991), the direct normal radiation $I_{b_{n}}$, expressed as a function of the direct horizontal radiation $I_{b}$, follows in Equation 13:

$I_{b_{n}}=\frac{I_{b}}{\cos (\theta)}$

Where:

- $I_{b_{n}}$ is the global horizontal radiation in $\mathrm{W} / \mathrm{m}^{2}$;

- $I_{b}$ is the horizontal direct radiation in $\mathrm{W} / \mathrm{m}^{2}$;

- $\theta$ is the zenith angle in degrees. 
Finally, direct normal radiation values are corrected based on maximum values for clear sky days, according to ASHRAE (2001), as cited by LabEEE (2005), following Equations 14 and 15:

$I_{b_{n_{\text {max }}}}=\frac{A}{\exp \left(\frac{B}{\sin (\beta)}\right)}$

Where:

- $I_{g}$ is the global horizontal radiation in $\mathrm{W} / \mathrm{m}^{2}$;

- $I_{b_{n_{\max }}}$ is the maximum direct normal radiation in $\mathrm{W} / \mathrm{m}^{2}$;

- $A$ is a monthly coefficient in $\mathrm{W} / \mathrm{m}^{2}$, according to Table 4;

- $B$ is a monthly coefficient, according to Table 4;

- $\quad \beta$ is the solar altitude in degrees.

And:

$\sin (\beta)=\cos (\varphi) \cdot \cos (\delta) \cdot \cos (\omega)+\sin (\varphi) \cdot \sin (\delta)$

Where:

- $\quad \beta$ is the solar altitude in degrees;

- $\varphi$ is the local latitude in degrees;

- $\delta$ is the declination of the terrestrial globe in degrees;

- $\omega$ is the hour angle in degrees, where: $\{\omega \in \mathbb{R} \mid-180 \leq \omega \leq 180\}$.

Table 4 - Coefficients $A$ and $B$ to calculate the maximum direct normal radiation

\begin{tabular}{cccccccccccccc}
\hline & Jan. & Feb. & Mar. & Apr. & Mar. & Jun. & Jul. & Aug. & Sep. & Oct. & Nov. & Dec. \\
\hline $\boldsymbol{A}$ & 1230 & 1215 & 1186 & 1136 & 1104 & 1088 & 1085 & 1107 & 1151 & 1192 & 1221 & 1233 \\
\hline $\boldsymbol{B}$ & 0.142 & 0.144 & 0.156 & 0.180 & 0.196 & 0.205 & 0.207 & 0.201 & 0.177 & 0.160 & 0.149 & 0.142 \\
\hline
\end{tabular}

Source: adapted from LabEEE (2005).

\section{Test Reference Year estimate}

The only data available for synthesizing the weather file of Pecém were hourly data for the year 2012, while the year 1979 was used by the SWERA project as a Test Reference Year for the city of Fortaleza. Given the proximity between the two localities, a Test Reference Year was estimated for the district of Pecém based on Equation 16 below:

$D_{P_{T R Y}}=D_{P_{2012}}+D_{F_{T R Y}}-D_{F_{2012}}$

Where:

- $D_{P_{T R Y}}$ is the monthly average for each data of the estimated TRY for the district of Pecém;

- $D_{P_{2012}}$ is the monthly average for each data of Pecém in the year 2012, measured or calculated by recommended methods;

- $D_{F_{T R Y}}$ is the monthly average for each data of the TRY of Fortaleza, obtained from the SWERA file;

- $D_{F_{2012}}$ is the monthly average for each climatic data of Fortaleza in the year 2012, from the World Weather Online website 4 .

After obtaining the monthly averages for all necessary variables to assemble the Pecém Test Reference Year, hourly values for the whole year were estimated based on the 
hourly values of the preliminary weather file of the year 2012, which was built based on measurements and recommended estimates. This calculation was performed through the software Elements, where the values of the year 2012 were adjusted to generate the monthly average calculated by Equation 16 .

\section{Tests}

In order to compare the generated TRY file for Pecém with files referring to Fortaleza and the year 2012 of Pecém, tests were performed through the thermal energy simulation platform, Euclid.

The test consisted of modeling a simple building, as shown in Figure 4, with standard materials for each type of surface and subsurface: floor, roof, walls, door, and windows. The model consisted on one thermal zone only, with thermal loads configured to 5.382 people per square dekameter; $10.7639 \mathrm{~W} / \mathrm{m}^{2}$ of installed power density for artificial lighting, and the same value for the installed power density for electrical equipment; without gas use; 2.36 liters per second per person as outdoor air renewal rate per person, and 0.305 liters per second per square meter as outdoor air renewal rate per area; and an infiltration rate of 0.5 (Figure 5). The default materials were set according to Figure 6.

Figure 4 - Building used for thermal energy simulations
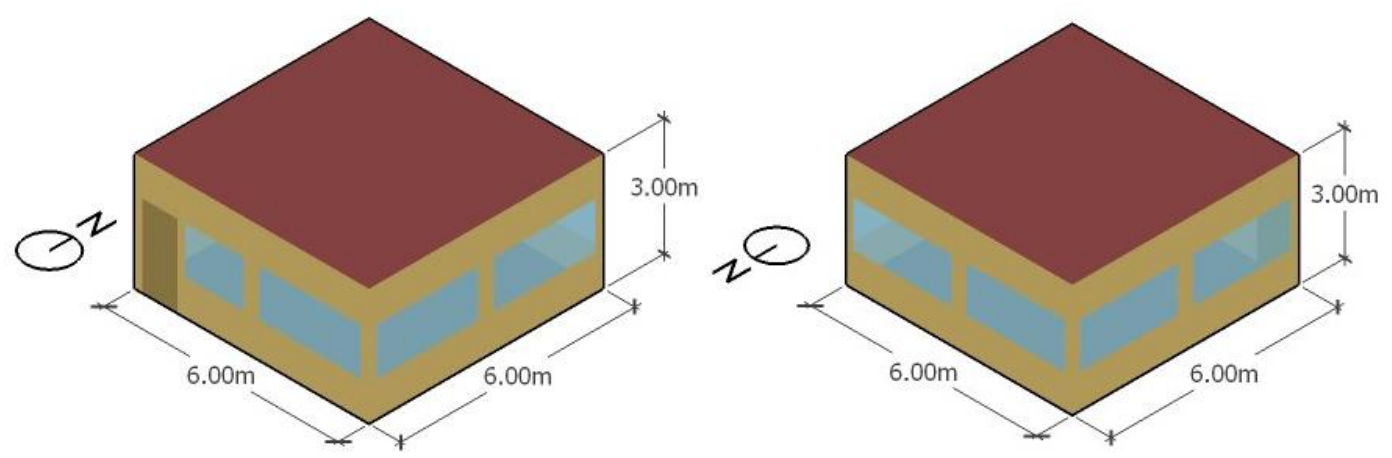

Source: The authors.

The schedule settings for occupancy, activity, lighting, use of electrical equipment, and outdoor air renewal per person were according to the standard for offices included in the software. The schedule setting of the outdoor air renewal rate by area is that of "always-on", and "on half the time" for the infiltration schedule (Figure 5).

The simulations were performed for three cases: 1) with the Test Reference Year file of Pecém; 2) with the weather file of the year 2012 of Pecém, and 3) with the Test Reference Year file of Fortaleza. The average temperatures of the internal and external surfaces, the mean radiant temperature and the dry bulb temperature of the thermal zone were compared. The comparisons were performed for the monthly averages and are presented further ahead in this work.

\section{Results}

\section{Definition of the global horizontal radiation method of estimation}

According to the technical report of LabEEE (2005), the application of the Kasten method presented more significant distortions to the main data source from which the reference values for global horizontal radiation estimation were taken — the Brazilian Solar Irradiation Atlas (COLLE; PEREIRA, 1998). However, when applying this method to compile the weather file of Pecém, the estimates could not be compared with real values of radiation measured on-site, since they do not exist. Still, the estimates 
PASSOS, J.A.A.; RAVIOLO, B. P. Y; MOTA, N. M. C. T.; CASTRO, N. H. B.; ANDRADE, K. C.; CARDOSO, D. R.

Synthesizing Test Reference Year files from known climate patterns of nearby cities

presented inconsistencies that could be detected in the calculation of the direct transmission coefficient of the global horizontal radiation.

Figure 5 - Thermal loads settings
People per Zone Floor Area (Number of People/100 $\left.\mathrm{m}^{2}\right)$ :
Occupancy Schedule:

Source: The authors.

Using the values estimated by the Kasten method to calculate the Equation 9 (LIU; JORDAN, 1960) in, the average of the diffuse transmission coefficients for the Pecém weather file for the year 2012 resulted in 0.2792 , which means that, on average, $27.92 \%$ of the extraterrestrial radiation arrives diffusely on the horizontal terrestrial tangent surface. However, calculations obtained by this method estimated values of global horizontal radiation and extraterrestrial radiation that result in an average clarity $K_{t}$ of 0.2512. $K_{t}$ is the ratio between global radiation and extraterrestrial radiation, which means that $25.12 \%$ of the extraterrestrial radiation is assigned to the sum of the diffuse and direct portions of radiation incident on the Earth's surface. Since this percentage is lower than the calculated only for the diffuse portion of radiation, it implies a negative direct transmission factor and, consequently, a negative direct horizontal radiation, invalidating the method for this research. 
Thus, the method adapted from Pitta (LabEEE, 2005) was applied, since it did not have any mathematical inconsistency in the calculation of the radiation. The failures of this method were foreseen, being only for the values above the maximum limit of normal direct radiation $I_{b_{n_{m a ́ x}}}$, that is, for the earliest and latest hours of the day, which could be corrected, as shown in Figure 7 for the first day of January.

Figure 7 - Correction for maximum direct normal radiation levels

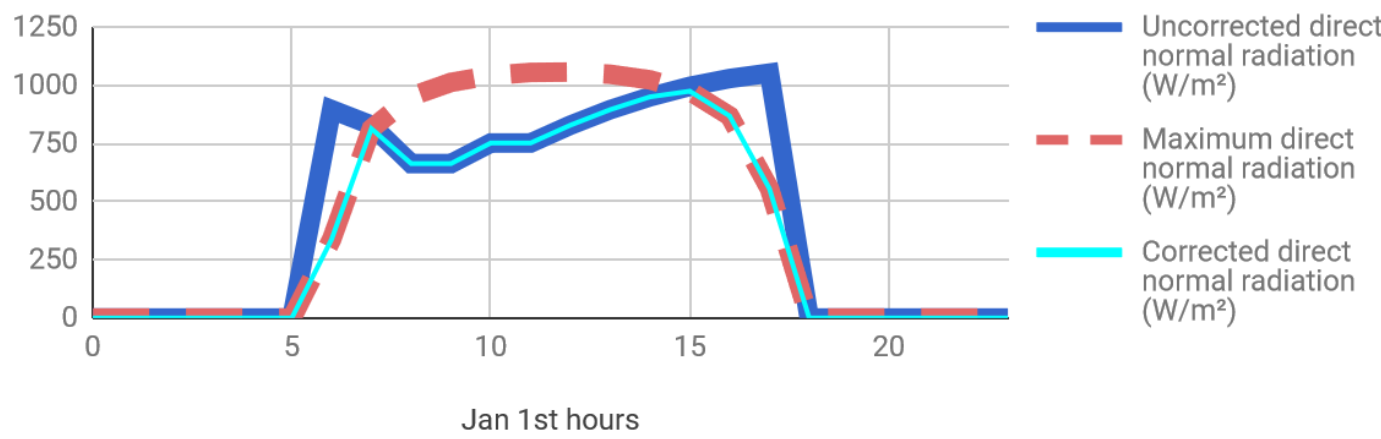

Source: The authors.

\section{Thermal energy simulations}

The results of the thermal energy simulations presented a few differences between the file for the year 2012 and Pecém's Test Reference Year for the average of the internal surface temperatures of the period between May to July. Also, values were always below the averages of Fortaleza (Figure 8). For the external surfaces, the months of January to April presented very similar average temperatures, with less than $0.4{ }^{\circ} \mathrm{C}$ of amplitude, with values, also, always below those obtained for Fortaleza (Figure 9). The averages for mean radiant temperature presented the most substantial difference between the simulations of both weather files for Pecém, with March and December of the year of 2012 firmly approaching the values of Fortaleza's Test Reference Year (Figure 10). The most considerable divergences between the curves of the three comparisons occurred in September and October, reaching more than $2{ }^{\circ} \mathrm{C}$.

Figure 8 - Internal surfaces average temperatures (monthly averages) $\left({ }^{\circ} \mathrm{C}\right)$

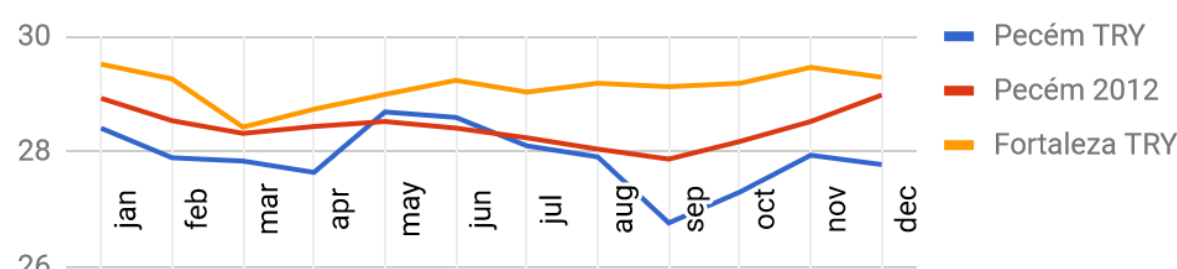

24

Source: The authors.

Figure 9 - External surfaces average temperatures (monthly averages) $\left({ }^{\circ} \mathrm{C}\right)$

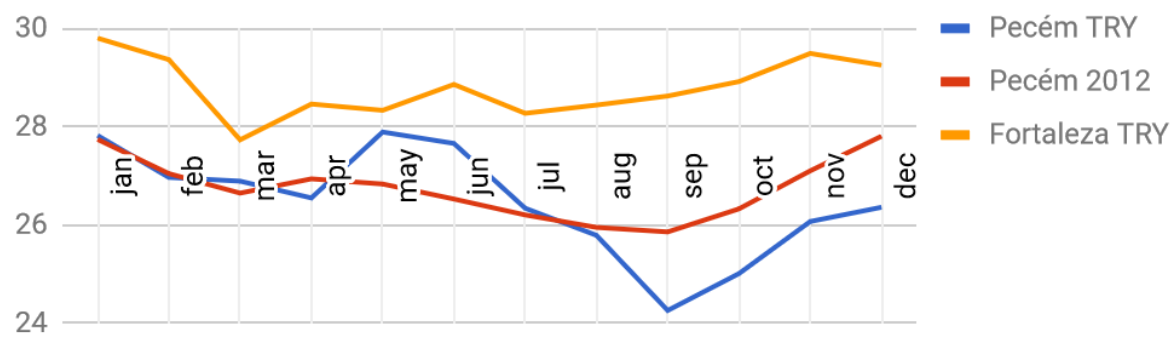

Source: The authors. 
PASSOS, J.A.A.; RAVIOLO, B. P. Y; MOTA, N. M. C. T.; CASTRO, N. H. B.; ANDRADE, K. C.; CARDOSO, D. R.

Synthesizing Test Reference Year files from known climate patterns of nearby cities

Figure 10 - Mean radiant temperatures of the thermal zone (monthly averages) $\left({ }^{\circ} \mathrm{C}\right)$

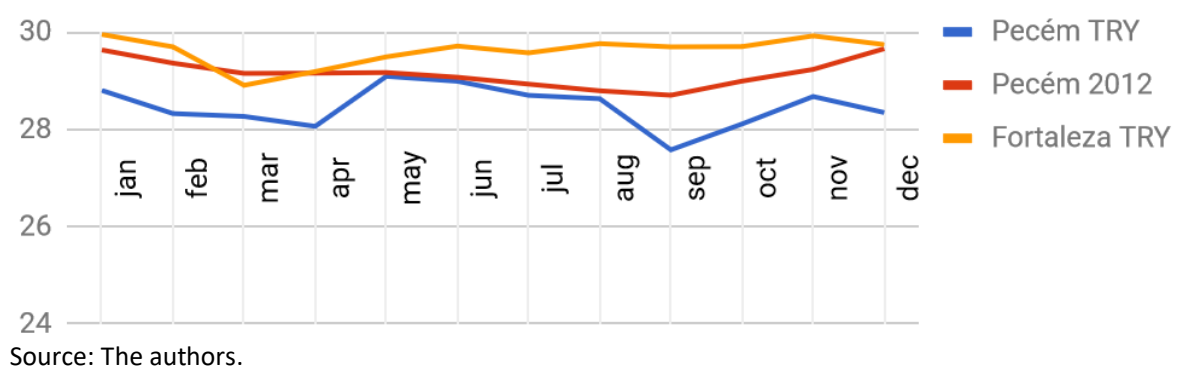

\section{Pecém's Test Reference Year weather file}

Figures 11, 12, 13, 14, and 15 show absolute data for the TRY file of Pecém, also used in comparative studies with Fortaleza's TRY. The histograms are for dry bulb temperature, direct normal radiation, diffuse horizontal radiation, global horizontal radiation, and cloud cover, respectively.

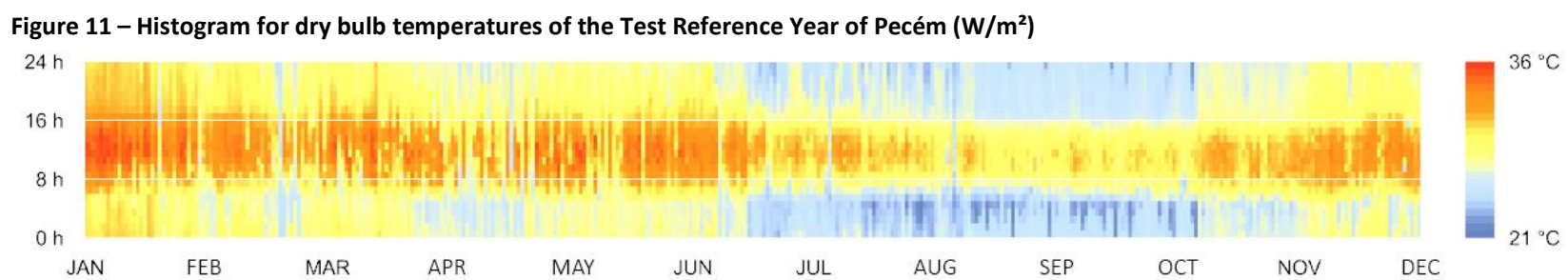

Source: The authors.

Figure 12 - Histogram for direct normal radiation of the Test Reference Year of Pecém $\left(\mathrm{W} / \mathrm{m}^{2}\right)$

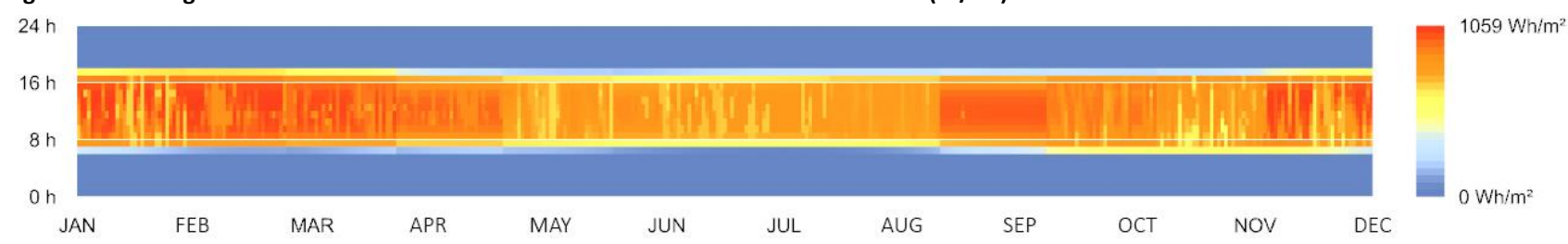

Source: The authors.

Figure 13 - Histogram for diffuse horizontal radiation of the Test Reference Year of Pecém $\left(\mathrm{W} / \mathrm{m}^{2}\right)$

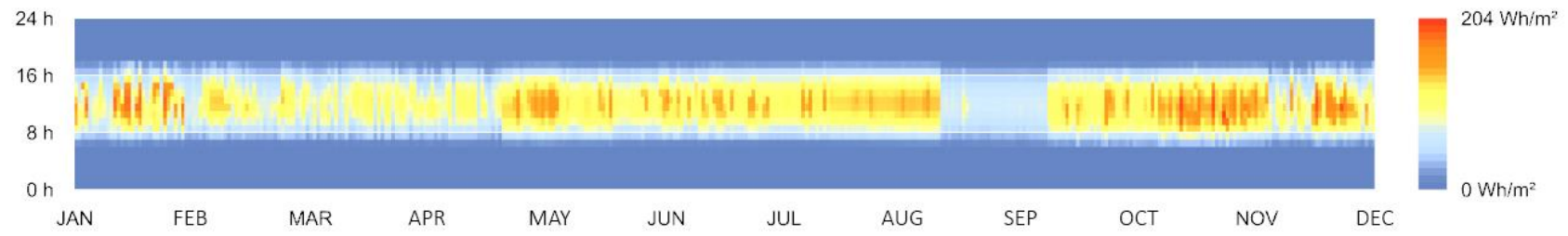

Source: The authors.

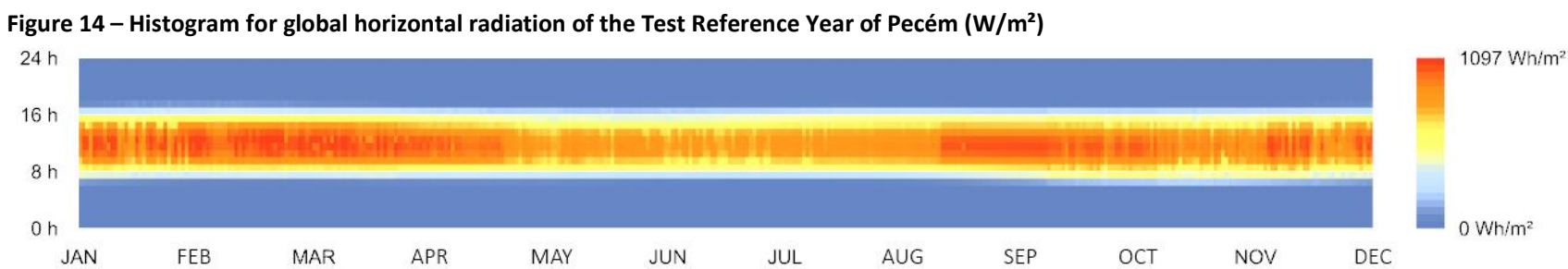

Source: The authors. 
PASSOS, J.A.A.; RAVIOLO, B. P. Y; MOTA, N. M. C. T.; CASTRO, N. H. B.; ANDRADE, K. C.; CARDOSO, D. R.

Synthesizing Test Reference Year files from known climate patterns of nearby cities

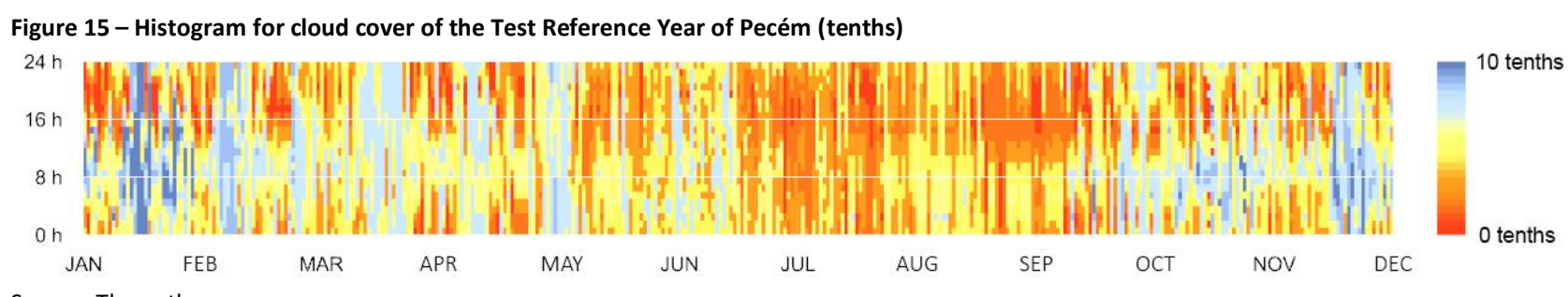

Source: The authors.

\section{Further discussions}

Problems were found with the Kasten method. In the application of the model, very low values of global horizontal radiation were generated, which resulted in negative values of direct horizontal radiation when the Liu and Jordan equations were applied to determine the direct and diffuse radiation fractions. These equations may also have interfered in generating invalid values, due to their creation for studies performed predominantly for higher latitudes. However, without the use of correction coefficients, the Pitta method made use of these same equations, producing much more plausible values, similar to those of Fortaleza, for the estimated radiations. Figures 16, 17, and 18 compare the radiation histograms of the TRY weather files of the two locations, showing a subtraction between Pecém and Fortaleza values, respectively. Smaller differences of direct normal radiation for Pecém were observed closer to noon, and higher values were observed during the earliest and latest hours of the day, probably due to the adaptation to the maximum curve calculated by ASHRAE (2001) coefficients.

The results suggest that a better way should be proposed to reduce the estimated values to within the curves with known maximum values. The used technique, although recommended, is still too simple for the mediation between both deductive (estimative) and inductive (maximum limits) processes.

Figure 16 - Histogram for the differences of global horizontal radiation between the Test Reference Years of Pecém and Fortaleza (W/ $\mathrm{m}^{2}$ )

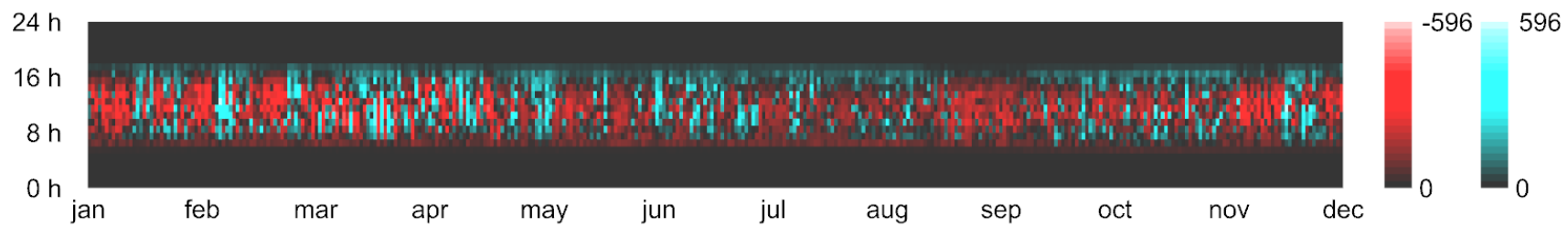

Source: The authors.

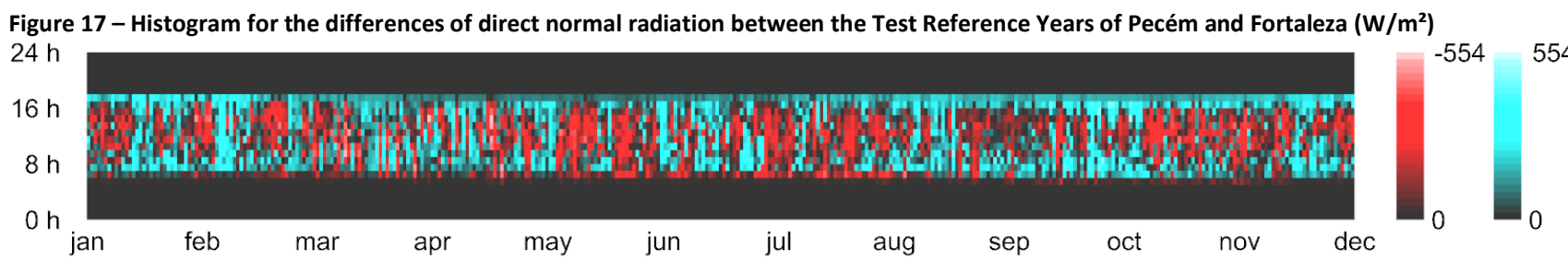

Source: The authors.

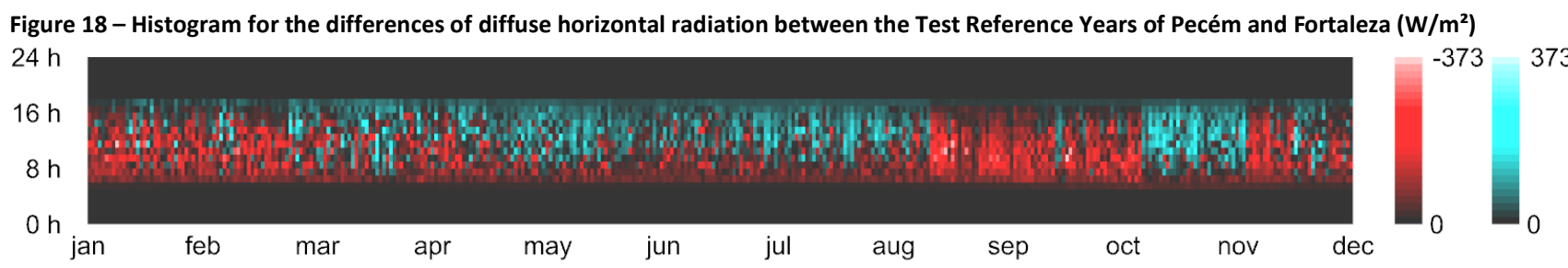

Source: The authors. 
Also, Figure 19, which compares the cloud cover histograms of the two localities, shows much higher values for Pecém during precisely the same months of lower temperatures obtained in the thermal energy simulations. Suggesting an explanatory correlation between the variables, as seen in Figure 20, that shows the differences of external surface temperature and cloud cover (tenths) monthly averages between Pecém (TRY) and Fortaleza (TRY). Figure 19 shows dry bulb temperature differences, showing colder hours in the same portions of the histogram, where greater cloud coverage was predicted in Pecém.

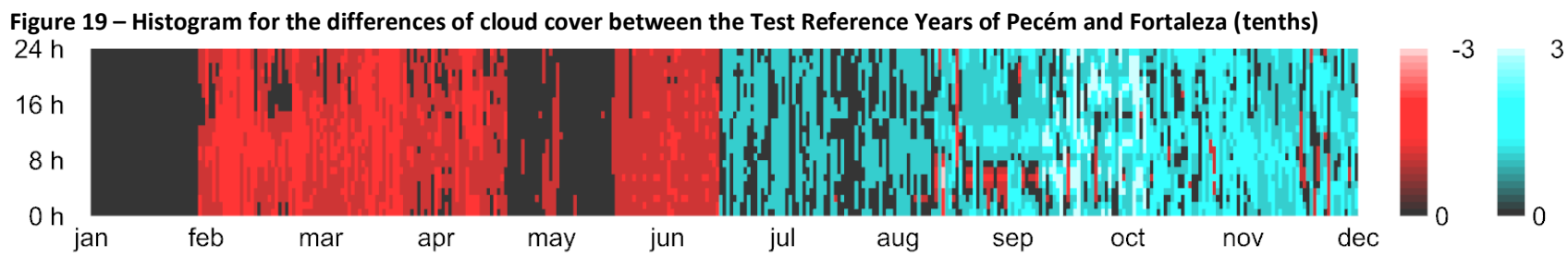

Source: The authors.

Figure 20 - Differences of external surface temperature $\left({ }^{\circ} \mathrm{C}\right)$ and cloud cover (tenths) monthly averages between Pecém (TRY) and Fortaleza (TRY)
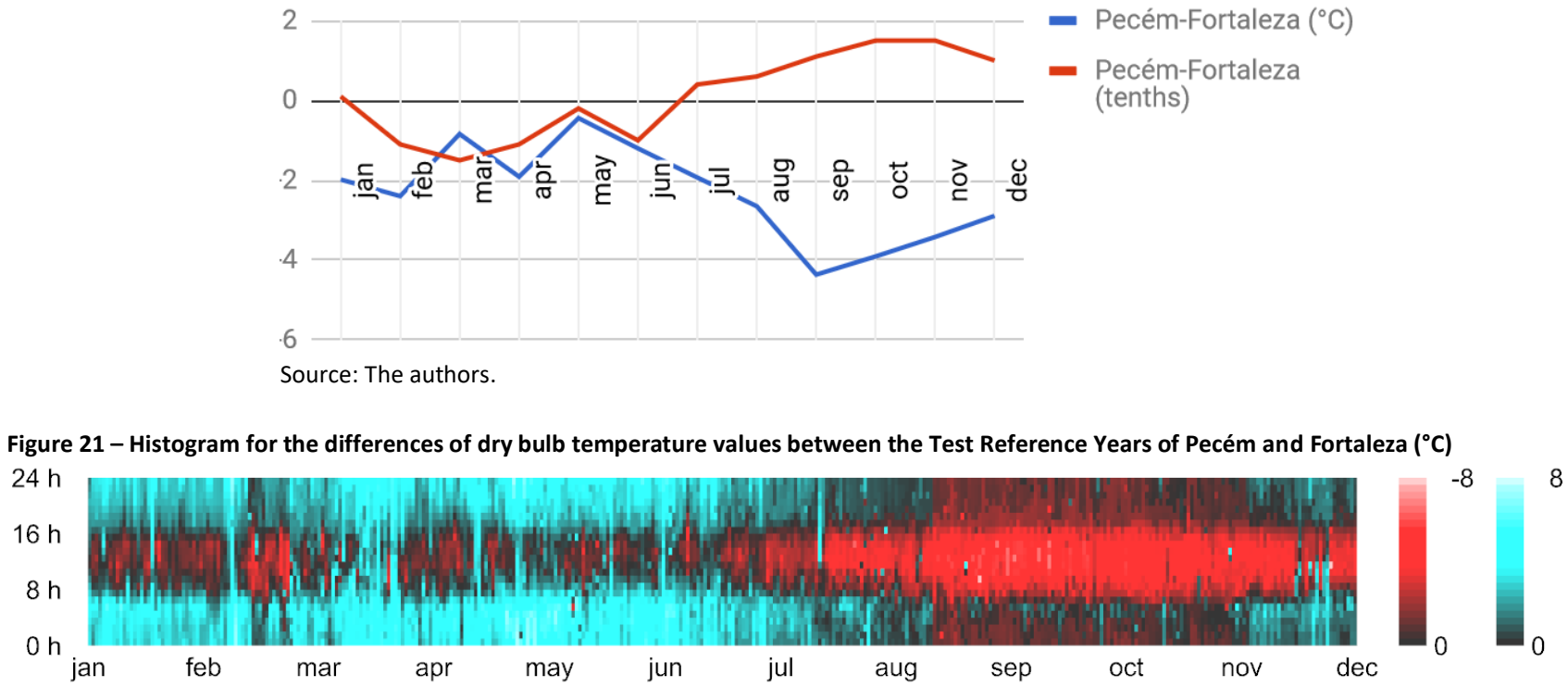

Source: The authors.

Although maximum differences of $30 \%$ in specific hours of the year were found for cloud cover values between both TRY files for Pecém and Fortaleza, those are concentrated in very brief and scattered periods of September and October. Most of Figure 19, then, is showing differences of less than $10 \%$ along the rest of the year, which is still relevant for the differences found in the results of the thermal energy simulations.

\section{Conclusions}

This study has implemented a technique that resulted in a specific weather file for a location of interest, which, when analyzed through thermal energy simulations, showed differences compared to results from simulations carried out with a weather file of a city $40 \mathrm{~km}$ distant. The differences were of up to $4{ }^{\circ} \mathrm{C}$ in monthly averages of surface temperatures of a simulated building, as well as up to $2^{\circ} \mathrm{C}$ in monthly averages of mean radiant temperatures.

We understood that, even if a specific locality is close to cities with weather files compatible with the simulation software to be used, the simple assumption that all 
climate variables will be identical may be a mistake. Adaptations to already obtained climatic data may be necessary due to site contextualization involving: different vegetation conditions, urbanization, a significant presence of water bodies, among others.

As future steps, this work intends to extend the developed method of estimation of Test Reference Years using other nearby localities, incorporating statistical regression techniques to treat a higher number of variables, which is a more straightforward method than performing measurements in loco.

\section{Acknowledgements}

The authors would like to thank the National Agency of Electrical Energy (ANEEL) and Portugal Energies (EDP) for the encouragement and financial support that made this research possible.

\section{Notes}

(1) A TRY weather file is obtained through a multi-year data analysis. By eliminating the years of higher and lower monthly mean temperatures, the remaining average data year is defined as the Year Reference Climate (GOULART; LAMBERTS; FIRMINO, 1997).

(2) SWERA. Solar and Wind Energy Resource Assessment. Available at: https://openei.org/wiki/Solar_and_Wind_Energy_Resource_Assessment_(SWERA). Accessed in: April 6, 2018.

(3) EnergyPlus Weather File - weather file format compatible with EnergyPlus, the thermal and energy simulation engine used in this research project.

(4) WORLD WEATHER ONLINE. Available at: https://www.worldweatheronline.com/. Accessed in: April 6, 2018.

(5) SOLAR RADIATION DATA. Linke turbidity factor. Available at: http://www.soda-pro.com/help/generalknowledge/linke-turbidity-factor. Accessed in: April 6, 2018

\section{References}

ABNT - ASSOCIAÇÃO BRASILEIRA DE NORMAS TÉCNICAS. NBR 15.220: Desempenho térmico de edificações. Rio de Janeiro, RJ, Abril de 2005.

ASHRAE - AMERICAN SOCIETY OF HEATING, REFRIGERATING AND AIR-CONDITIONING ENGINEERS. Fundamentals Handbook. Atlanta: ASHRAE, 2001.

ASSEMBLÉIA LEGISLATIVA DO ESTAdo Do CEARÁ. Pacto pelo Pecém: Cenário Atual do Complexo Industrial e Portuário do Pecém. Fortaleza, Ceará, 2013.

BARNABY, S. C.; CRAWLEY, B. D. Weather data for building performance simulation. In: HENSEN, J.; LAMBERTS, R. Building Performance Simulation for Design and Operation. London: Spon Press, 2011. p.37-55.

CAMPBELL SCIENTIFIC, INC. WXT510 Weather Transmitter: Instruction Manual. Available at: https://s.campbellsci.com/documents/us/manuals/wxt510.pdf. Accessed in: April 6, 2018.

COLLE, S.; PEREIRA, E. Atlas de Irradiação solar do Brasil. $1^{\text {a }}$ versão. Brasília: INMET, 1998.

DUFFIE, John A.; BECKMAN, William A. Solar Engineering of Thermal Processes. 2. ed. New York: Willey Interscience, 1991.

FERREIRA, T. S.; BUORO, A. B. Estudo de alternativas para melhoria do desempenho energético de uma edificação comercial em São Paulo. Revista de Iniciação Científica, Tecnológica e Artística. Edição Temática em Sustentabilidade, São Paulo, v. 5, n. 3, dez. 2015. p. 85-100. 
PASSOS, J.A.A.; RAVIOLO, B. P. Y; MOTA, N. M. C. T.; CASTRO, N. H. B.; ANDRADE, K. C.; CARDOSO, D. R.

Synthesizing Test Reference Year files from known climate patterns of nearby cities

GONÇALVES, J. C. S.; BRUNELLI, G.; BODE, K. Projeto integrado e o papel da simulação computacional de desempenho ambiental (exemplos de projeto). In: GONCALVES, J. C. S; BODE, K. (Org.). Edifício Ambiental. São Paulo: Oficina de Textos, 2015, cap. 9..

GOULART, S.; LAMBERTS, R.; FIRMINO, S. Dados climáticos para projeto e avaliação energética de edificações para 14 cidades brasileiras. Florianópolis: UFSC, 1997. 345p.

LabEEE - LABORATÓRIO DE EFICIÊNCIA ENERGÉTICA EM EDIFICAÇÕES. Relatório 200504: processamento de arquivos climáticos para simulação do desempenho energético de edificações. Florianópolis: 2005. Available at: http://www.labeee.ufsc.br/sites/default/files/arquivos_climaticos/RT200504.pdf. Accessed in: April 6, 2018.

LIU, B. Y. H.; JORDAN, R. C. The Interrelationship and Characteristic Distribution of Direct, Diffuse and Total Solar Radiation. Solar Energy, v. 4, 1960. p.1-19. DOI: http://dx.doi.org/10.1016/0038-092X(60)90062-1.

NREL - NATIONAL RENEWABLE ENERGY LABORATORY. User's manual for TMY2s and TMY2sm tipical metorological years derived from the 1961-1990. Colorado: NREL, 1995.

PITTA, T. O. Estudo de métodos diretos e indiretos de estimativa de irradiação solar global diária horizontal a partir de observações superficiais de cobertura total de nuvens em Florianópolis, SC. 2001, 115 p. Dissertação (Mestrado em Engenharia Civil) - Programa de Pós-graduação em Engenharia Civil - Universidade Federal de Santa Catarina, Florianópolis.

SUPPORT, W. W. O. Personal message. Received by <bruno.raviolo@gmail.com> in: 10 Mar, 2019.

THEVENARD, D.; BRUNGER, A. Typical weather years for international locations. Final Report Research Project 1015-RP. ASHRAE, 2001.

\section{José Aderson Araújo Passos Filho}

Architect. Specialist, Masters student. Postal address: Avenida da Universidade, 2890, Fortaleza, CE, Brazil, CEP 60020-181.

${ }^{2}$ Bruno de Paiva y Raviolo

Architect. Postal address: Avenida da Universidade, 2890, Fortaleza, CE, Brazil, CEP 60020-181.

\section{Natasha Maria Catunda Torres Mota}

Architect. Masters student. Postal address: Altstetterstrasse 183, 8048, Zurich, ZH, Switzerland.

4 Nayana Helena Barbosa de Castro

Architect. Masters student. Postal address: Rua Antônio Augusto, 39, Fortaleza, CE, Brazil. CEP 60110-370.

\section{Karoline Cordeiro de Andrade}

Architect. Specialist. Postal address: Avenida da Universidade, 2890, Fortaleza, CE, Brazil, CEP 60020-181.

\section{Daniel Ribeiro Cardoso}

Architect. PhD. Professor of the Federal University of Fortaleza. Postal address: Avenida da Universidade, 2890, Fortaleza, CE, Brazil, CEP 60020-181. 